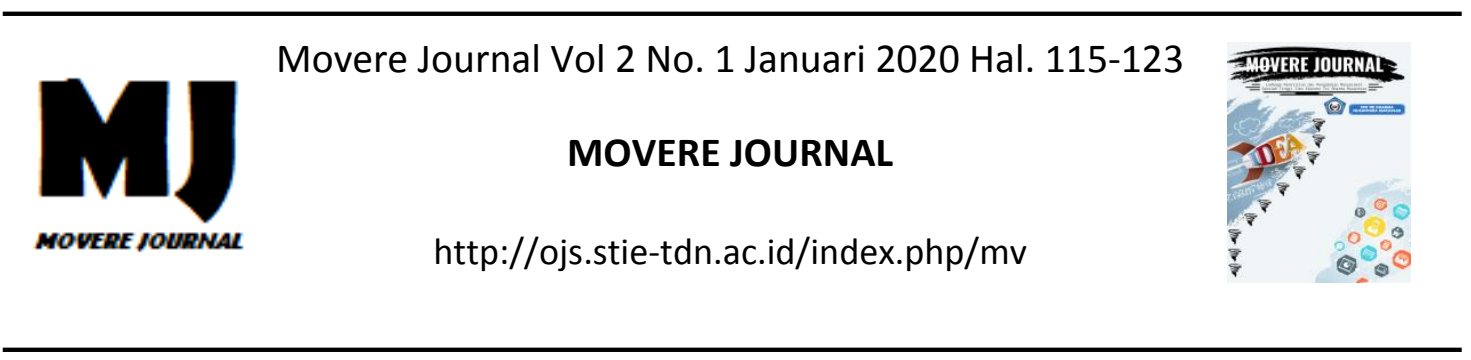

\title{
PENGARUH WEBSITE QUALITY DAN TRUST TERHADAP LOYALITAS PELANGGAN LAZADA PADA FAKULTAS EKONOMI DAN BISNIS ISLAM UINSU MEDAN
}

\author{
Wan Dian Safina \\ Universitas Muslim Nusantara Al-wasliyah Medan
}

\begin{abstract}
Abstrak : Penelitian ini bertujuan untuk mengalisis dan mengetahui seberapa besar pengaruh website quality dan trust terhadap loyalitas pelanggan Lazada. Penelitian ini mengunakan sampel sebanyak 44 responden. Teknik pengumpulan data dalam penelitian ini adalah dengan menyebarkan angket (kuesioner). Hasil kolerasi menunjukkan hubungan yang kuat dengan nilai kolerasi 0,658 dan nilai $\mathrm{R}$ squdare $\left(\mathrm{R}^{2}\right)=\mathrm{O}, 658$ atau $65,8 \%$ menunjukkan bahwa secara simultas variabel Website Quality dan Trust mempunyai penagruh sebesar 65,8\% terhadap Loyalitas Pelanggan. Hasil penelitian ini menyatakan pengaruh variabel Website Quality $\left(\mathrm{X}_{1}\right)$ dan Trust $\left(\mathrm{X}_{2}\right)$ ditunjukkan dari hasil analisis regresi ganda $\mathrm{Y}=2,998+0,747 \mathrm{X}_{1}+0,148 \mathrm{X}_{2}$. Hal ini berarti jika terjadi peningkatan variabel Website Quality dan Trust, maka Loyalitas Pelanggan Lazada akan menigkat.
\end{abstract}

Kata kunci : Website Quality, Trust Dan Loyalitas Pelanggan

\section{PENDAHULUAN}

Memasuki era globalisasi saat ini, terutama dalam bidang teknologi informasi menjadikan internet tidak hanya berfungsi sebagai alat komunikasi, melainkan sudah merambah kepada interaksi yang lebih kompleks. Banyak situs dan aplikasi untuk belanja secara online dalam beberapa tahun ini. Pembelian produk secara online terjadi dikarenakan adanya perkembangan teknologi yang semakin canggih sehingga banyak masyarakat ataupun mahasiswa yang memilih untuk berbelanja secara online yang dinamis dan ekonomis sehingga dapat memerlukan kemudahan, kecepatan dan akurat dalam melakukan sebuah transaksi. Hal ini membuka peluang bagi industri komersial di Indonesia, atau disebut dengan $e$ commerce.

Belanja online atau online shopping saat ini telah menjadi cara baru bagi sebagian masyarakat Indonesia dalam berbelanja. Online shopping dianggap menjadi sebuah solusi bagi sebagaian orang, karena konsumen online shopping dapat memperoleh barang atau jasa yang diinginkannya tanpa harus pergi ke tempat perbelanjaan, tetapi cukup memilih apa yang diinginkannya dengan membuka website yang disediakan oleh penyedia penjual online dan membayar dengan cara

C 2020 STIE TDN. All rights reserved 
mentransfer uang ke penjual. Dengan demikian para pembeli dapat menghemat waktu yang lebih efektif dan efisien untuk mendapatkan barang atau jasa yang diperlukan

\section{Identifikasi Masalah}

1. Tingkat kepercayaan masyarakat terhadap transaksi online masih rendah.

2. Persepsi negatif masyarakat terhadap online shopping masih tinggi.

3. Loyalitas pengunjung Lazada masih tergolong rendah.

\section{Rumusan Masalah}

1. Apakah ada pengaruh website quality terhadap loyalitas pelanggan Lazada ?

2. Apakah ada pengaruh trust terhadap loyalitas pelanggan Lazada ?

3. Apakah ada pengaruh website quality ,trust terhadap loyalitas pelanggan Lazada?

4. Seberapa pengaruh website quality dan trust terhadap loyalitas pelanggan Lazada?

\section{Tujuan Penelitian}

1. Untuk mengetahui pengaruh website quality terhadap loyalitas pelanggan Lazada.

2. Untuk mengetahui pengaruh trust terhadap loyalitas pelanggan Lazada.

3. Untuk mengetahui pengaruh website quality, trust terhadap loyalitas pelanggan Lazada.

4. Untuk mengetahui seberapa besar pengaruh website quality dan trust terhadap pelanggan Lazada

\section{Manfaat Penelitian}

a. Menjadi sarana bagi penulis untuk mengembangkan penalaran dan membentuk pola pikir ilmiah dan untuk mengetahui kemampuan penulis dalam menerapkan ilmu-ilmu manajemen yang dipelajari dalam perkuliahan.

b. Memberikan pengetahuan dan pengalaman baru bagi penulis mengenai analisis website quality, trust dan loyalitas pelanggan Lazada.

\section{TELAAH LITERATUR DAN PENGEMBANGAN HIPOTESIS}

\section{Website Quality (Kualitas Website)}

Dalam penelitian yang dilakukan oleh Sorum (2014) dalam jurnal Bambang Eko Samiono (2018:39), menyatakan bahwa website quality adalah segala aspek yang berkaitan dengan informasi dan layanan online, aspek desain dan fitur teknis yang harus dijalani customer selama interansaksi online dengan website

\section{Dimensi Website Quality}

Menurut Sugianto

dalam jurnal Bambang Eko Samiono (2018:39), mengungkapkan bahwa para penelitian terdahulu membagi dimensi kualitas website menjadi enam, yaitu :

1. Information (Informasi)

2. Ease of Use (Kemudahan Pemakaian)

3. Fullfilment/Reliability (Reliabel)

4. Site Design (Desain Situs)

5. Security/ Privasy (Keamanan)

6. Interativity (Pelayanan Interaktif)

\section{Peran Website dalam E-commerce} Menurut Butter dan Goritz (2008) dalam penelitian Bayu Andika (2016:14), Website merupakan suatu komponen yang sangat penting dalam e-commerce, hal ini dikarenakan 
pembeli tidak dapat melihat secara langsung tentang produk yang ditawarkan oleh penjual. Website berfungsi penyalur informasi yang ingin disampaikan penjual kepada pembeli, oleh sebab itu kepercayaan pembeli sepenuhnya bergantung pada seluruh informasi yang disampaikan penjual dalam website yang disediakan oleh penjual.

\section{Trust (Kepercayaan)}

Menurut Sumarwan dalam buku Etta Mamang Sangadji (2013:201), kepercayaan adalah kekuatan bahwa suatu produk memiliki atribut tertentu. Kepercayaan itu sering disebut perkaitan objek-atribut (objectattribute lingkage), yaitu kepercayaan konsumen tentang kemungkinan adanya hubungan antar sebuah objek dengan atribut yang relevan. Dapat disimpulkan bahwa kepercayaan seperti perlu diperhatikan oleh para $e$ commerce sehingga pembeli akan merasa nyaman untuk berbelanja dan memeberikan data pribadi seorang pembeli tersebut pada toko online.

\section{Dimensi Trust}

Menurut Champ dalam Chai \& Piew (2010) dalam jurnal Bambang Eko Samiono (2018:40), dimensi online trust sebagai berikut :

1. Security (Keamanan)

2. Privacy (Privasi)

3. Reability (Realibitas)

\section{Kepercayaan dalam $\boldsymbol{E}$-commerce}

Menurut Koufaris dan Hampton-Sosa dalam Greagg dan Walczak (2010) dalam penelitian Bayu Andika (2016:13), kepercayaan dari pelanggan mempunyai peranan yang sangat penting dalam e-commerce. Terutama dengan banyaknya isu "penipuan" dan beragam bentuk ke tidak jujuran lain dalam e-commerce. Sehingga menjadikan pelanggan pun enggan untuk mulai berbelanja atau menggunakan jasa e-commerce. Ketika pelanggan sudah memiliki kepercayaan pada $e$ - commerce maka dengan otomatis akan mendapatkan loyalitas dari pelanggan tersebut untuk bertransaksi dengan menggunakan $e$ commerce.

\section{Loyalitas Pelanggan}

Menurut Oliver dan Hurriyati dalam buku Etta Mamang Sangadji (2013:104) menyatakan bahwa loyalitas adalah berlangganan kembali atau melakukan pembelian ulang produk atau jasa terlebih secara konsisten di masa yang akan tayang, meskipun pengaruh situasi dan usahausaha pemasaran mempunyai potensi untuk menyebabkan perubahan prilaku. Dalam Griffin dalam buku Etta Mamang Sangadji (2013:104), “ loyality is defined as non rondom purchase expressed over time by some decision making unit."

\section{Dimensi Loyalitas Pelanggan}

Menurut Tjiptono (2002) dalam buku Vinna Sri Yuniati, Se, MM (2015:242) mengemukakan enam indikator yang dapat digunakan untuk mengukur loyalitas pelanggan, yaitu sebagai berikut :

1. Pembelian ulang.

2. Kebiasaan mengonsumsi merek tersebut.

3. Selalu menyukai merek tersebut.

4. Tetap memilih merek tersebut.

5. Yakin bahwa merek tersebut yang baik.

6. Merekomendasikan merek tersebut kepada orang lain.

Prinsip-Prinsip Loyalitas Pelanggan

Menurut Kotler dalam buku Etta Mamang Sangadji (2013:109) ada tujuh prinsip pokok loyalitas pelanggan, yaitu : 
1. Kemitraan yang didasarkan pada etika dan integritas yang utuh

2. Nilai tambah, seperti kualitas, biaya, waktu siklus, teknologi, profitabilitas dan sebagainya

3. Sikap yang saling percaya antara konsumen dan perusahaan

4. Keterbukaan antara pelanggan dan perusahaan
5. Pemberian bantuan secara aktif dan konkret

6. Tindakan berdasarkan semua unsur antusiasme konsumen

\section{Kerangka Konseptual}

Kerangka Konsep dalam penelitian ini dapat dilihat pada gambar berikut ini :

\section{WEBSITE QUALITY}

(X1)

1. Information (Informasi)

2. Ease of use (Kemudahan Pemakaian)

3. Fullfliment/Realibility (Reliebel)

4. Sife design (Desain Situs)

5. Security/privacy (Keamanan)

6. Interativity (Pelayanan Interaktif)

Menurut Sugianto (2016)

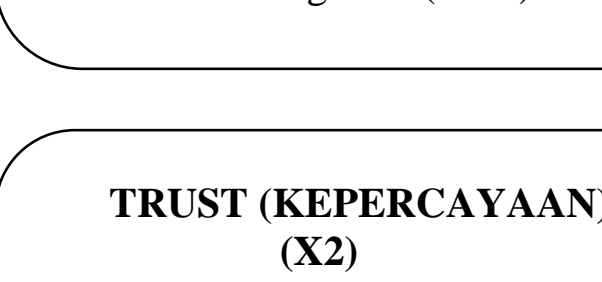

1. Security (Keamanan)

2. Privacy (Privasi)

3. Realibilitas (Realibilitas )

Menurut Champ dalam

Chai \& Piew (2010),

\section{Hipotesis}

1. H1 : Diduga ada pengaruh yang signifikan antara Website

\section{LOYALITAS \\ PELANGGAN}

(Y)

1. Pembelian ulang.

2. Kebiasaan mengonsumsi merek tersebut.

3. Selalu menyukai merek tersebut.

4. Tetap memilih merek tersebut.

5. Yakin bahwa merek tersebut yang baik.

6. Merekomendasikan merek tersebut kepada orang lain.

Menurut Tjiptono (2002) dalam buku Vinna Sri Yuniati, Se,
Quality terhadap Loyalitas pelanggan Lazada.

2. H2 : Diduga ada pengaruh yang signifikan antara Trust 
terhadap Loyalitas Pelanggan

Lazada.

3. H3 : Diduga ada pengaruh yang signifikan antara Website

Quality dan Trust terhadap

Loyalitas Pelanggan Lazada.

\section{METODE PENELITIAN}

Penelitian ini dilakukan di Universitas Islam Negeri Sumatera Utara Fakultas Ilmu Bisnis Islam Jurusan Perbankan Syariah semester enam. Penelitian di lakasanakan selama 4 bulan yang di mulai dari bulan januari sampai dengan April 2019. Adapun yang menjadi variabel independent dalam penelitian ini adalah "kualiatas Web (X1) dan Trust (X2). Dan yang menjadi variabel dependent adalah Loyalitas pelanggan (Y). Adapun Analisis data Penelitian ini adalah Analisis regresi linier Berganda, Hasil perhitungan uji $t$ (parsial), uji F dan uji R2 (koefesien determinasi ) yang diperoleh dengan menggunakan program SPSS 22,0

\section{HASIL PENELITIAN}

\section{Pembahasan}

Analisis Regresi Linier Berganda
1. Konstanta (a) sebesar 2,998 menunjukkan bahwa tanpa adanya variabel website quality dan trust pada pelanggan Lazada adalah 2,998.

2. Website Quality (X1) sebesar 0,747 menunjukkan bahwa variabel website quality berpengaruh positif dan signifikan terhadap trust, artinya setiap peningkatan website quality, maka akan berpengaruh positif terhadap trust atau kepercayaan pelanggan Lazada.

3. Trust/kepercayaan (X2) sebesar 0,148 menunjukkan bahwa variabel trust berpengaruh positif dan signifikan terhadap loyalitas pelanggan Lazada, artinya setiap terjadi peningkatan variabel trust, maka akan berpengaruh positif terhadap peningkatan loyalitas pelanggan Lazada

Uji T

Hasil Uji Parsial

Coefficients $^{\mathrm{a}}$

\begin{tabular}{|c|c|c|c|c|c|}
\hline \multirow[b]{2}{*}{ Model } & \multicolumn{2}{|c|}{$\begin{array}{l}\text { Unstandardized } \\
\text { Coefficients }\end{array}$} & \multirow{2}{*}{\begin{tabular}{|c|}
$\begin{array}{c}\text { Standardized } \\
\text { Coefficients }\end{array}$ \\
Beta \\
\end{tabular}} & \multirow[b]{2}{*}{$\mathrm{l}$} & \multirow[b]{2}{*}{ Sig. } \\
\hline & B & Std. Error & & & \\
\hline $1 \quad$ (Constant) & 2,998 & 4,810 & & ,623 &, 537 \\
\hline $\begin{array}{l}\text { Website } \\
\text { Quality }\end{array}$ & ,747 & , 108 & ,737 & 6,918 &, 000 \\
\hline Kepercayaan & 148 &, 123 & ,129 & 1,209 & ,234 \\
\hline
\end{tabular}

a. Dependent Variable: Loyalitas

Sumber : Hasil pengolahan data menggunakan SPSS 22.0 (2019) 
Berdasarkan tabel di atas diperoleh nilai :

1. Website quality (X1) memiliki nilai $t_{\text {hitung }}(6,918>1,682)$ dengan tingkat signifikan 0,000 $<0,05$. Artinya website quality (X1) berpengaruh signifikan terhadap Loyalita pelanggan Lazada (Y).
2. Trust/kepercayaan

(X2) memiliki nilai $\mathrm{t}_{\text {hitung }}(1,209<$ 1,689) dengan tingkat signifikan $0,234>0,05$. Artinya trust tidak berpengaruh signifikan terhadap Loyalitas pelanggan Lazada

Uji F

ANOVA $^{\mathrm{a}}$

\begin{tabular}{|ll|r|r|r|r|r|}
\hline \multicolumn{2}{|l|}{ Model } & \multicolumn{1}{|c|}{$\begin{array}{c}\text { Sum of } \\
\text { Squares }\end{array}$} & df & $\begin{array}{c}\text { Mean } \\
\text { Square }\end{array}$ & F & Sig. \\
\hline 1 & Regression & 877.216 & 2 & 438.608 & 37.389 & $.000^{\mathrm{b}}$ \\
& Residual & 480.966 & 41 & 11.731 & & \\
& Total & 1358.182 & 43 & & & \\
\hline
\end{tabular}

a. Dependent Variable: Loyalitas

b. Predictors: (Constant), Kepercayaan, Website_Quality

Sumber : Data primer diolah, 2019

Berdasarkan tabel di atas menunjukkan bahwa nilai $F_{\text {hitung }} 37,389>F_{\text {tabel }} 3,22$ dan nilai signifikan $0,000<0,05$. Kriteria $\mathrm{F}_{\text {hitung }}>\mathrm{F}_{\text {tabel }}$ dan nilai signifikan $<0,05$. Maka Ha diterima, artinya terdapat pengaruh yang signifikan antara Website Quality dan Trust secara bersama-sama terhadap Loyalitas pelanggan Lazada UINSU Medan.

\section{Uji Determinasi $\left(\mathbf{R}^{2}\right)$}

\begin{tabular}{|l|c|r|r|c|}
\hline Model & R & R Square & $\begin{array}{c}\text { Adjusted R } \\
\text { Square }\end{array}$ & $\begin{array}{c}\text { Std. Error of the } \\
\text { Estimate }\end{array}$ \\
\hline 1 &, $811^{\mathrm{a}}$ &, 658 &, 641 & 3,17840 \\
\hline
\end{tabular}

a. Predictors: (Constant), Kepercayaan, Website Quality

Sumber : Data primer diolah, 2019

Berdasarkan tabel di atas, dapat dilihat niali R Squad diperoleh sebesar 0,786. Untuk melihat besar pengaruh variabel bebas terhadap variabel terikat dengan cara menghitung Koefesien Determinasi $(\mathrm{KD})=\mathrm{R}^{2} \mathrm{x} 100 \%$, sehingga diperoleh KD 65.8\%. Angka tersebut menunjukkan bahwa sebesar
$65,8 \%$ loyalitas pelanggan (variabel terikat) dapat dijelaskan oleh variabel website quality dan trust/kepercayaan. Sisanya sebesar 34,2\% dipengaruhi faktor-faktor lain yang tidak dijelaskan dalam penelitian ini.

(C) 2020 STIE TDN. All rights reserved 


\section{KESIMPULAN DAN SARAN}

\section{Kesimpulan}

1. Berdasarkan uji regresi linier berganda, maka diperoleh persamaan nilai konstanta sebesar 2,998 dan nilai koefisien regresi 0,747 , sehingga diperoleh persamaan regresi linier sederhana dengan rumus $\mathrm{y}=\mathrm{a}+\mathrm{bx} 1+\mathrm{bx} 2+\mathrm{e}, \mathrm{Y}$ $=2,998+0,747 X_{1}+0,148 X_{2}$ + e, dimana Website Quality dan Trust mempunyai pengaruh yang signifikan terhadap variabel Loyalitas pelanggan.

2. Berdasarkan uji $t$ diketahui bahwa hasil yang diperoleh dari pertunjukan Website quality $\left(\mathrm{X}_{1}\right)$ memiliki nilai $\mathrm{t}_{\text {hitung }}(6,918$ $>1,689)$ dengan tingkat signifikan $0,000<0,05$. Artinya website quality $\left(\mathrm{X}_{1}\right)$ berpengaruh signifikan terhadap Loyalita pelanggan Lazada (Y).

3. Trust/kepercayaan $\left(\mathrm{X}_{2}\right)$ memiliki nilai $t_{\text {hitung }}(1,209$ $<1,689)$ dengan tingkat signifikan 0,234 >0,05. Artinya trust tidak berpengaruh signifikan terhadap Loyalitas pelanggan Lazada.

4. Dari hasil pengujian hipotesis pada uji F (simultan) pada variabel Website Quality dan Trust diperoleh nilai $F_{\text {hitung }}$ $37,389>F_{\text {tabel }} 3,23$ dengan ini maka hipotesis $\mathrm{H} 0$ ditolak dan Ha diterima. Sehingga dapat disimpulkan bahwa variabel Website Qualitu $\left(\mathrm{X}_{1}\right)$ dan Trust $\left(\mathrm{X}_{2}\right)$ secara simultan berpengaruh signifikan terhadap Loyalitas pelanggan (Y), dengan tingkat signifikan $0,000<0,05$. Berdasarkan hal tersebut maka dapat dijelaskan jika Website Quality dan Trust secara bersama-sama berpengaruh signifikan terhadap Loyalitas pelanggan Lazada pada mahasiswa Fakultas Ekonomi dan Bisnis Islam UINSU Medan. Berdasarkan hasil ini hipotesis diterima.

5. Niali $R$ Squad diperoleh sebesar 0,658. Untuk melihat besar pengaruh variabel bebas terhadap variabel terikat dengan cara menghitung Koefesien Determinasi $(\mathrm{KD})=$ $\mathrm{R}^{2} \times 100 \%$, sehingga diperoleh KD $65.8 \%$. Angka tersebut menunjukkan bahwa sebesar $65,8 \%$ Loyalitas pelanggan (variabel terikat) dapat dijelaskan oleh variabel Website Quality dan Trust/kepercayaan. Sisanya sebesar $34,2 \%$ dipengaruhi faktor-faktor lain yang tidak dijelaskan dalam penelitian ini.

\section{Saran}

1. Dari hasil penelitian dapat dilihat bahwa Website Quality dan Trust memberikan pengaruh terhadap Loyalitas pelanggan. Oleh karena itu Lazada

diharapkan dapat meningkatkan kedua variabel tersebut, sehingga nantinya diharapkan dapat meningkatkan Loyalitas pelanggan dalam membeli produk Lazada yang pada akhirnya akan bermuara pada pencapaian laba perusahaan secara maksimal.

2. Dari hasil penelitian dapat dilihat bahwa Website Quality dan Trust berpengaruh terhadap Loyalitas pelanggan, tetapi pengaruhnya masih dalam kategori cukup baik dan belum dalam kategori lebih baik. Oleh 
karena itu, pihak manajemen perusahaan Lazada khususnya bagian marketing hendaknya memperhatikan dan terus meningkatkan dan mengembangkan kedua variabel terikat dan menjadikannya sebagai strategi pemasaran dengan cara memberikan jaminan kepada pelanggan seperti uang kembali jika produk atau barang yang dipesan tidak sesuai dengan aslinya atau barang yang dipesan tidak sampai.

3. Bagi para konsumen atau pelanggan khususnya mahasiswa muslim dalam melakukan keputusan pembelian haruslah didasarkan kepada kebutuhan bukan hanya sekedar keinginan maupun gaya hidup (life style) atau pun trend yang ada saat ini.

4. Bagi penelitian berikutnya, jika skripsi ini digunakan sebagai referensi, maka hendaknya dikaji ulang karena penulis menyadari bahwa skripsi ini masih jauh dari sempurna.

\section{DAFTAR PUSTAKA}

Buku :

Arikunto, Suharsimi. 2017. Prosedur

Penelitian Suatu Pendekatan Praktik,Cetakan Ke

Empat Belas. PT. Rineka Cipta, Jakarta

Ghozali, Imam, 2016. Aplikasi Analisis Multivariete Dengan Program IBM SPSS 23.

Semarang : Badan Penerbit Universitas Dipenogoro

Kotler Philip, Kevin Lane Keller, 2013. Manajemen Pemasaran, Edisi Ketiga. Cetakan Erlanggan. Jakarta
Ling, Kwek Choon, Lau Tock Chai dan Tan Hoi Piew. "the effects of shopping ori

Malau, Harman, 2018. Manajemen Pemasaran Teori Dan Aplikasi Pemasaran Era Tradisonal

Sampai Eran Moderanisasi Global. Cetakan kedua, Alfabeta. Bandung

Nugroho, Adi Sulistyo, 2016. Ecommerce; Teori dan Implikasi. Cetakan Pertama, Yogyakarta

Priyanto, Dwi. 2011. SPSS (Analisis Statistik Data), Mediakom. Yogyakarta

.Sangadji, Etta Mamang, 2013. Prilaku Konsumen. Yogyakarta

Sudaryono. 2016. Manajemen Pemasaran Teori Dan Implikasi. Edisi i. $\mathrm{Cv}$ andi offset.

Yogyakarta

Sugiono,2016. Metodologi Penelitian Kuantitatif, Kualitatif dan $R \& D$. Cetakan ke Dua Puluh Tujuh, Alfabeta. Bandung.

Sugiono,2017. Metodologi Penelitian Kuantitatif, Kualitatif dan $R \& D$. Cetakan ke Dua Puluh Tujuh, Alfabeta. Bandung.

Yuniarti, Vinna Sri. 2015. Perilaku Konsumen Teori dan Prkatik. Cetakan pertama, Bandung

Jurnal :

Ulva Mustikarani Hanifah dan Bambang Eko Samiono (2018) Analisis Pengaruh Website Quality Dan Ewom Purchase Decision Melalui Online Trust Pada Situs Tiket Trivel Dan Reservasi Hotel Online Di Indonesia)

Hotlan Siagian dan Edwin Cahyono (2014). Analisis Website Quality, Trust Dan Loyalty Pelanggan Lazada. 
Skripsi :

Bayu andika (2016) Analisis Website

Quality,Trust Dan Loyalitas

Pelanggan Lazada Studi

Kasus Masyarakat Kota

Yogyakarta 